\title{
THE CURRENT STATUS OF HYPNOSIS IN SPAIN
}

\author{
Adolfo J. Cangas* and Graham F. Wagstaff** \\ *Department of Clinical Psychology, University of Almería, Spain, and \\ **Department of Psychology, University of Liverpool, UK
}

\begin{abstract}
While Spanish academic researchers have actively attempted to disengage hypnosis from its traditional links with altered states and automatism, and to promote it by linking hypnotic phenomena with other everyday psychological processes, in the legal field there seems to have been little activity. Among jurists, opinion is divided regarding the exact influence of hypnosis on conscious will, although some maintain that hypnosis can override will, and most that being in a state of hypnosis at the time of committing a criminal act can be used as a defence, depending on knowledge of the prior personality of the individual and the kind of suggestions given. Consequently, because of its alleged influence on will, hypnosis is forbidden by law in Spain as an investigative procedure. Likewise, the practice of hypnosis has been removed from Spanish public health system services, and it cannot be subsidized by private insurance companies. We conclude that traditional notions of hypnosis may be holding back its practical acceptance in Spain.
\end{abstract}

Key words: hypnosis, Spain, law, forensic, sophrology, self-regulation

\section{Introduction}

As ties between countries in Europe develop, it is of both interest and importance to examine how colleagues from different countries view the topic of hypnosis and its applications. In this paper we look briefly at how the Spanish view hypnosis.

In Spain and its surrounding countries there seems to have been a recent upsurge of interest in hypnosis. This is reflected not only in the number of researchers or professionals currently devoted to its study, which has grown noticeably during the past decade, but in its social repercussions (Capafons, 1999).

Thus, for example, there is a greater demand for training in the techniques of hypnosis. The number of workshops and courses has grown throughout the Spanish territory, and perhaps most notable is the course for specialists in 'Hypnosis, Techniques and Applications' currently being taught at the Complutense University in Madrid.

This increase in professional interest in hypnosis has also been echoed in the entertainment world. Hence, stage hypnosis shows can be found on several Spanish television channels; there was even one programme devoted exclusively to hypnosis as entertainment a few years ago.

However, hypnosis is by no means a novel phenomenon in Spain (MontserratEsteve, 1964). The 1960s saw the emergence of a very important movement in favour of the use of hypnosis for medical purposes, which still exists in specializations such as dentistry, obstetrics and psychiatry. Its founder, Dr Caycedo, was one of the creators of the first clinical hypnosis departments in Spain, at the Provincial Hospital of Madrid. 


\section{Hypnosis and sophrology}

In the daily practice of hypnosis, Caycedo and his team repeatedly reported what they considered to be anomalies in the phenomena associated with hypnosis, such as the fact that only on exceptional occasions did patients respond to suggestions for posthypnotic amnesia and, when this occurred, it was relatively easy to coax the patient into remembering what had happened. Their experiences with suggested anaesthesia were not very uniform either; in many cases considerable anaesthesia was achieved, even sufficient for surgery, with what seemed to be a superficial state of hypnosis, whereas in other cases, subjects under apparently deep hypnosis did not experience suggested anaesthesia. Also, when patients were told that they were going to be hypnotized, this seemed to evoke in them many negative attitudes and expectations which seemed to interfere with the therapeutic process. It was eventually suggested, therefore, that the term hypnosis be eliminated and substituted by something more appropriate (Caycedo, Pons and Sarro, 1969; Pons, 1973).

To this end, the term 'sophrology' was chosen, taken from the Greek 'sophrosynen' which Plato used in the Carmides to refer to the effect produced on the body by beautiful words. Sophrology denotes the influence of verbal action on the organism which, in the age of Plato, included prayers, psalms and 'terpnos logos'. The last was less magical than the first two and includes the use of soft, monotonous, persuasive words, which is, sophrologists affirm, how language is used in hypnosis (Boon, Davrou and Macquet, 1978).

The sophrology movement, influenced by phenomenology and by certain oriental practices, attempted to approach the study of consciousness from a strictly scientific point of view. Many of its techniques originated in the autogenic training schemes of Schultz and the progressive relaxation programmes of Jacobson, plus certain oriental practices such as yoga, Buddhism or Zen. The use of relaxation, in particular, was highlighted (in the form of 'dynamic relaxation') and one is reminded here of the emphasis which researchers such as Edmonston (1991) have placed on this process in hypnosis.

Sophrology spread quickly throughout a number of countries, including those in South America, as well as France, Switzerland and India, where sophrology societies were created (Caycedo et al., 1969), and two world congresses were held in Barcelona in 1970 and 1975, each of them attended by more than a thousand professionals from over 55 countries (Boon et al., 1978). At present, the techniques of sophrology are still used by certain medical practitioners, mainly in the specializations mentioned above, as well as in the psychology of sports, although sophrology's popularity has waned somewhat in recent years.

\section{Self-regulation therapy and active-alert hypnosis}

In an independent attempt to avoid negative connotations associated with the word 'hypnosis' in clinical practice, another group of researchers, in this case at the University of Valencia, is currently promoting the use of techniques usually associated with hypnosis, but without labelling them as such (Amigó, 1990; Capafons and Amigó, 1993; Amigó and Capafons, 1996). It is argued that these might constitute another resource, within the techniques of behaviour modification, which might improve the attractiveness of therapy, and motivation and interest of clients (Amigó, 1990). These techniques are collectively known as 'self-regulation therapy', and the 
American Psychological Association has published a text which includes information on their clinical use (Kirsch, Capafons, Cardeña and Amigó, 1999).

Investigations are also being conducted into active hypnosis methods, as a way of creating positive attitudes and expectations towards therapy. Thus, in contrast to the typical conception of the hypnotized individual as someone in a state of deep relaxation accompanied by sleepiness, and so on, the client's eyes are kept open and emphasis is placed on the control he or she may exercise by staying alert. Such techniques have been labelled 'awake-alert hypnosis' and 'rapid self-hypnosis' (Capafons, 1998a,b; Cardeña, Alarcon, Capafons and Bayot., 1998) and are familiar in the general hypnosis literature (see, for example, Bányai and Hilgard, 1976; Malott, 1984).

\section{Forensic aspects of hypnosis in Spain}

However, despite the increasing popularity of hypnosis in both the entertainment and academic and clinical domains, there seems to be little interest in Spain in hypnosis from a legal perspective. In fact, it is difficult to find legal texts that treat the matter directly. Indeed, the most frequently cited case in the Spanish literature was a crime committed in Denmark in 1951, in which one person allegedly hypnotized another and ordered him to rob a bank (Morillas, 1987).

Spanish authors seem to be divided on the question of whether hypnosis may provoke subjects into a state of automatism, powerless to resist suggestions, or whether they are perfectly conscious and in control of their actions. Following the German tradition, some Spanish authors have argued that hypnosis could be included within the category of what is known as 'irresistible force', in which a person who has been subjected to an external irresistible force is considered exempt of responsibility. This concept is differentiated from another category known as 'insurmountable fear', because, according to this view, hypnosis allegedly does not act on motivation or will, but rather passes over or bypasses them (being an absolute physical force) (Mir, 1996: 188).

However, this view, which was previously reflected in Exemption 9 of Article 8 in the old Spanish Penal Code, no longer expressly appears in the New Penal Code of 1995. Apparently, the reason for this is that the assumptions underlying the defence of 'irresistible force' are included in the general definition of crime in Article 10 ('Crimes or offences are fraudulent or imprudent actions and omissions penalized by the law'); that is, for a behaviour to be a crime, (1) the offender must possess the capacity to understand the injustice of the deed; (2) the offender must possess the capacity to act according to this understanding; and (3) the action must be penalized by law (Luzón, 1996). The status of hypnosis within this, however, now seems less explicit.

It has also been argued that hypnosis could fall within another section of the Spanish Penal Code, governing 'absence of action' as in 'states of unconsciousness', in which, in addition to hypnosis, sleep and lethargic drunkenness would also be included. It is assumed, again, that, in these cases, the defendant or victim also has neither the consciousness nor the will to carry out the action.

Some writers have argued that 'the criminal suggestion during hypnotic sleep or during a post-hypnotic period is obeyed only if the hypnotized subject is neurotic or psychopathic with criminal tendencies' (Cerezo, 1997: 64). Other authors, following the doctrine of the psychiatrist Vallejo Nájera, express the view that hypnotized subjects can never completely lose consciousness of their acts and if they commit a crime under the suggestion of the hypnotist, they do so following their tendencies, the resulting crime being beneficial for both hypnotist and hypnotized (quoted in Morillas, 1987). Nevertheless, although it cannot be claimed that hypnosis overrides 
the will, guilt may be excluded or attenuated on grounds of alteration of mental balance (Article 20,1st) or, if all the requirements necessary for that exemption are not fulfilled, for 'transitory mental alteration' (Article 21).

Possibly the doctrine most followed by Spanish jurists is what is known as an intermediate position between the automatism and free-will positions (Romero, 1992). From this point of view, it becomes fundamental to know the personality of the subject, the circumstances of the case and the type of suggestion. Thus, it has been pointed out that although a hypnotized person may commit a minor crime, there is a strong resistance under hypnosis to committing major crimes. However, exceptionally a 'weak' person might be found not guilty on grounds related to the unconsciousness or the 'irresistible force' arguments indicated above. Also, if any psychopathological signs should be observed in the defendant, the defendant could allege alteration of mental balance or the transitory mental alteration, as previously described.

Some of the complexities involved are described by Luzón (1996) as follows:

If in certain cases it is found that the person hypnotized has completely lost consciousness of reality and in that condition performs a deed, either by commission or omission, due to unconscious impulse or suggestion of the hypnotist, there is no action. If he remains conscious, although only partially, and yields to the orders of the hypnotist, again it depends on the degree to which his will is affected; if this is rendered totally void by the hypnotist, again there is an assumption of lack of action analogous to irresistible force, but, if his will is under strong pressure, but without becoming annulled, there is action, although the charge may be affected or excluded. (1996: 281)

Given this, the role of the expert in the determination of the responsibility of the subject is therefore seen as particularly important.

However, on one point all writers seem to agree; the hypnotist should be incriminated for acts performed by the hypnotized subject (Quintero, Rorales and Prats, 1996). Thus, Romero states, 'although in the assumption that hypnosis does not completely render the will of the individual void, the instrument is also author, and the author used may be called "author after the author" (1992: 157). Of course, this would not apply if the person hypnotized sought hypnosis in order to commit a crime. In this case one would have to speak of the responsibility of the subject under the heading of fraud or imprudence if he or she did not intend to commit a crime, but could have foreseen it.

Regarding its use in police investigation, in Spain evidence given under hypnosis is considered as illicit evidence. In Spanish law, during interrogation of the accused or witnesses, techniques that may influence the person's free will or alter his or her critical capacity to evaluate his or her actions may not be used, and hypnosis falls into this category. Also, confession obtained by hypnosis or truth serums is implicitly prohibited by Article 15 of the Spanish Constitution as degrading to human beings. Thus, even if the accused himself were to so request, hypnosis would not be permitted; a point clearly stated in the Sentence of the Supreme Court of 26 November 1991, in which it says that the methods of hypnosis may not be used in criminal investigation since they are considered an attack on human dignity and liberty. Hypnosis is also considered contrary to Statutory Law 6/1985 of 1 July, of the Judiciary Power, Article 11.1, which determines that 'evidence obtained directly or indirectly by violating the rights or fundamental liberties is not valid', and to the Law of Criminal Judgment, which clearly establishes that witnesses and other persons declaring must be in complete possession of their mental capacity, without pressure, coercion or suggestion (Articles 389 and 439). 


\section{Other limitations on the use of hypnosis}

Although legal writers have argued that hypnosis is applicable only within the framework of psychodiagnosis and psychotherapy, nevertheless it is also the case that hypnosis may not be used for medical purposes financed by public funds for health services. This is specified in Royal Decree 63/1995, of 20 January, on regulation of the National Health System services, in which, under Point 6 of Annex III, psychoanalysis and hypnosis are excluded from publicly financed health services. The reasons given for this are that there is insufficient scientific evidence on their clinical safety and efficiency. Likewise, insurance companies exclude treatment by hypnosis from private medical insurance policies, for the same reasons.

\section{Conclusions}

In sum, the Spanish 'experience' of hypnosis presents something of a paradox. On the one hand, legal and medical authorities display a mixture of credulity and scepticism; credulity in the traditional notion of hypnosis as a special state in which the will is influenced, and scepticism about its safety and efficacy. In these respects, the Spanish legal authorities seem to possess rather more set and robust views than those in Britain and the USA, where cases tend to be treated more on an individual basis (see, for example, Laurence and Perry, 1988; Wagstaff, 1999).

On the other hand, academic researchers in Spain seem to be adopting an opposing conception that: (1) rejects the traditional notion of hypnosis as a special state; yet (2) argues that many of the techniques associated with hypnosis may be clinically efficacious. In this way, academic researchers are embracing many of the views now adopted by sociocognitive theorists such as Kirsch, Lynn, Sarbin, Spanos and Wagstaff (see Lynn and Rhue, 1991), a point clearly made in the content and editorship of the recent APA publication entitled Clinical Hypnosis and Self-regulation: Cognitive-behavioral Perspectives (Kirsch et al., 1999).

The Spanish experience of hypnosis, therefore, seems to be one in which some of the more traditional notions of hypnosis could be said to be holding back its acceptance as a legitimate procedure that may have clinical benefits. At the same time, there seems to be little objection to its use for entertainment purposes. Although the position may not be as extreme in Britain, arguably, in some respects the same situation could be said to apply. Thus, while the recent British Home Office review has argued against a ban on stage performances of hypnotism, many practitioners of medicine remain dubious about the efficacy of hypnosis procedures and express concerns about their safety. Perhaps, as the views of academic researchers from both countries filter through to the other authorities, a more healthy and realistic balance may be obtained.

\section{References}

Amigó S (1990) Manual de Terapia de Autorregulación (Handbook for self-regulation therapy). Valencia: Promolibro.

Amigó S, Capafons A (1996) Emotional self-regulation therapy for treating primary dysmenorrhea and premenstrual distress. In SJ Lynn, I Kirsch (eds) Casebook of Clinical Hypnosis. Washington, DC: American Psychological Association, pp.153-71.

Bányai EI, Hilgard ER (1976) Comparison of active-alert hypnotic induction with traditional relaxation. Journal of Abnormal Psychology 85: 218-24. 
Boon H, Davrou Y, Macquet JC (1978) La sofrología (Sophrology). Madrid: Mensajero.

Capafons A (1998a) Rapid self-hypnosis: A suggestion method for self-control. Psicothema 10: 571-81.

Capafons A (1998b) Hipnosis clinica: Una vision cognitiva-comportamental (Clinical hypnosis: A cognitive-behavioural perspective). Papeles del Psicologo 69: 71-88.

Capafons A (1999) Hypnosis in Spain. Psychological Hypnosis 8: 7-8.

Cardeña E, Alarcon A, Capafons A, Bayot A (1998) Effects on suggestibility of a new method of active-alert hypnosis: Alert hand. International Journal of Clinical and Experimental Hypnosis 46: 280-94.

Capafons A, Amigó S (eds) (1993) Hipnosis, terapia de auto-regulacióne intervención comportamental (Hypnosis, self-regulation and behaviour treatment). Valencia: Promolibro.

Caycedo A, Pons A, Sarro R (eds) (1969) Progresos en sofrología (Progress in sophrology). Barcelona: Scientia.

Cerezo J (1997) Curso de Derecho Penal Español. Parte General (Course of Spanish Penal Law. General Part) (5th edition). Madrid: Tecnos.

Edmonston WE (1991) Hypnosis as relaxation. In SJ Lynn, JW Rhue (eds) Theories of Hypnosis. Current Models and Perspectives. New York: Guilford, pp.197-237.

Kirsch A, Capafons E, Cardeña E, Amigó S (1999) Clinical Hypnosis and Self-regulation: Cognitive-behavioral Perspectives. Washington, DC: American Psychological Association.

Laurence JR, Perry CW (1988) Hypnosis, Will and Memory: A Psycho-legal History. New York: Guilford.

Luzón D (1996) Curso de Derecho Penal: Parte General (Course of Penal Law: General Part). Madrid: Universitas.

Lynn SJ, Rhue JW (eds) (1991) Theories of Hypnosis: Current Models and Perspectives. New York: Guilford.

Malott JM (1984) Active-alert hypnosis: Replication and extension of previous research. Journal of Abnormal Psychology 93: 246-9.

Mir S (1996) Derecho Penal. Parte General (Penal Law: General Part). Barcelona: PPU.

Montserrat-Esteve S (1964) Historia de la hipnosis en España (The history of hypnosis in Spain). Revista de Psiquiatría y Psicología Médica 4: 575-84.

Morillas L (1987) La eximente penal de fuerza irresistible (The penal exemption from irresistible force). Granada: Universidad de Granada.

Pons JL (1973) Contribución a la historia de la hipnosis y de la sofrología en España. (Contribution to the hypnosis and sophrology history in Spain). Unpublished doctoral thesis, Faculty of Medicine, University of Barcelona.

Quintero G, Rorales F, Prats M (1996) Curso de Derecho Penal. Parte General (acorde con el Nuevo Codigo Penal de 1995) (Course of Spanish Penal Law. General part (according to the New Penal Code of 1995)). Barcelona: Cedecs.

Romero C (1992) Causas de exclusion de la accion (Causes that exclude the action). Cuadernos de Politica Criminal 46: 151-67.

Wagstaff GF (1999) Forensic hypnosis. In A Kirsch, E Capafons, E Cardeña, S Amigó (eds) Clinical Hypnosis and Self-regulation Cognitive-behavioral Perspectives. Washington, DC: American Psychological Association, pp.277-310.

\author{
Address for correspondence: \\ Adolfo J. Cangas \\ Department of Clinical Psychology, \\ University of Almería, \\ 04120-Almería, \\ Spain \\ Email: ajcangas@filabres.ualm.es
}

